\title{
PENGARUH KESELAMATAN DAN KESEHATAN KERJA (K3) TERHADAP JUMLAH PENYAKIT KERJA DAN JUMLAH KECELAKAAN KERJA KARYAWAN PADA PT. HANEI INDONESIA
}

\author{
Reza Indradi Putera ${ }^{1)}$, Sri Harini ${ }^{2)}$ \\ Program Studi Management Fakultas Ekonomi Universitas Djuanda Bogor \\ Email : rezaindradiputera@yahoo.com, sri.harini@unida.ac.id \\ Correpondence author: sri.harini@unida.ac.id
}

\begin{abstract}
The purpose of this study aims to influence health and safety (K3) to the number of occupational diseases and accidents the number of employees at PT. Hanei Indonesia. The data used for the study is a document of the company. Analysis of the data is processed using simple regression methods to determine the effect of health and safety on the number of occupational diseases and the number of work accidents, the correlation coefficient to determine the relationship, the coefficient of determination to find out the percentage and hypothesis analysis (t-test) to determine the significance of the cost of K3 to the number of disease employment and the number of work accidents. The results showed that the cost of K3 affect the number of ccupational diseases as well as the cost of $K 3$ on the number of workplace accidents.
\end{abstract}

\section{Keywords: Cost K3, Work Diseases and Accidents}

Tujuan penelitian ini bertujuan untuk pengaruh keselamatan dan kesehatan kerja (K3) terhadap jumlah penyakit kerja dan jumlah kecelakaan kerja karyawan pada PT. Hanei Indonesia. Data yang digunakan untuk penelitian adalah dokumen perusahaan. Analisis data tersebut diolah menggunakan metode regresi sederhana untuk mengetahui pengaruh keselamatan dan kesehatan kerja terhadap jumlah penyakit kerja dan jumlah kecelakaan kerja, koefisien korelasi untuk mengetahui hubungan, koefisien determinasi untuk mengetahui persentase serta analisis hipotesis (uji t) untuk mengetahui signifikasi biaya K3 terhadap jumlah penyakit kerja dan jumlah kecelakaan kerja. Hasil penelitian menunjukan bahwa biaya K3 berpengaruh terhadap jumlah penyakit kerja begitu juga biaya K3 terhadap jumlah kecelakaan kerja.

Kata kunci : Biaya K3, Penyakit Kerja dan Kecelakaan Kerja

\section{PENDAHULUAN}

Sumber daya manusia (SDM) merupakan salah satu aset dan salah satu bagian dari sebuah organisasi, karena itu Sumber daya manusia ini perlu pengelolaan dengan baik dan benar, jika dilihat dari sifatnya sumber daya manusia memiliki keunikan dari pada aset lainnya. Hal itu dikarenakan SDM ini memiliki perasaan, pikiran, dan perilaku, sehingga jika dikelola dengan baik mampu memberikan kontribusi bagi kemajuan perusahaan secara aktif, sesuai yang diungkapkan (Istijanto, 2010).

Perusahaan dalam mewujudkan tujuannya tidak jarang dihadapkan pada persoalan karyawan di dalam perusahaan maupun keluarga. Tekanan persoalan dapat berupaaspek emosional dan fisik, keselamatan dan kesehatan kerja, dan berlanjutpada terjadinya penurunan produktivitas karyawan. Pihak manajemen perusahaanseharusnya mampu mengakomodasi persoalan karyawan sejauh yang terkait dengan kepentingan perusahaan. Pertimbangannya adalah bahwa unsur keselamatan dan kesehatan karyawan memegang peranan penting dalam peningkatan mutu kerja karyawan. Semakin cukup kuantitas dan kualitas fasilitas keselamatan dan kesehatan kerja, maka semakin tinggi pula mutu kerja karyawannya. Dengan demikian perusahaan akan semakin diuntungkan dalam upaya pencapaian tujuannya (Mangkuprawira dan Aida, 2007).

Keselamatan dan Kesehatan Kerja (K3) merupakan satu upaya perlindungan yang diajukan kepada semuapotensi yang dapat menimbulkan bahaya. Hal tersebut bertujuan agar tenaga kerja dan orang lain yang ada ditempat kerja selalu dalam keadaan selamat dan sehat serta semua sumber produksi dapat digunakan secara aman dan efisien (Suma'mur, 2006). 
Perusahaan yang baik adalah perusahaan yang benar-benar menjaga keselamatan dan kesehatan karyawannya dengan membuat aturan tentang keselamatan dan kesehatan kerja yang dilaksanakan oleh seluruh karyawan dan pimpinan perusahaan. Perlindungan tenaga kerja dari bahaya dan penyakit akibat kerja atau akibat dari lingkungan kerja sangat dibutuhkan oleh karyawan agar karyawan merasa aman dan nyaman dalam menyelesaikan pekerjaannya. Tenaga kerja yang sehat akan bekerja produktif, sehingga diharapkan produktivitas kerja karyawan meningkat yang dapat mendukung keberhasilan bisnis perusahaan dalam membangun dan membesarkan usahanya.

Program pembangunan di Indonesia telah membawa kemajuan pesat disegala bidang kehidupan seperti sektor industri, jasa, properti, pertambangan, transportasi dan lainnya. Namun dibalik kemajuan tersebut ada harga yang harus dibayar masyarakat Indonesia, yaitu dampak negatif yang ditimbulkannya salah satu diantaranya adalah bencana seperti kecelakaan, pencemaran dan penyakit akibat kerja yang mengakibatkan ribuan orang cedera setiap tahunnya.

Kondisi ini disebabkan karena kurangnya kepedulian mengenai keselamatan dankesehatan kerja (K3) di tengah masyarakat. Proses pembangunan belum diimbangi dengan peningkatan kesadaran keselamatan dan kesehatan kerja sehingga bahaya dan resikonya terus meningkat.

Menurut laporan Internasional Labour Organization (ILO) tahun 2006 kerugian akibat kecelakaan kerja mencapai $4 \%$ dari GDP suatu negara. Artinya, dalam skala industri, kecelakaan dari penyakit akibat kerja menimbulkan kerugian 4 persen dari biaya produksi berupa pemborosan terselubung (hidden cost) yang dapat mengurangi produktivitas yang pada akhirnya dapat mempengaruhi daya saing suatu negara.

Hasil survey World Economic Forum tersebut juga mengkaitkan antara daya saing dengan tingkat keselamatan. Negara dengan daya saing rendah memiliki tingkat keselamatan yang rendah pula. Indeks daya saing Indonesia berada pada peringkat ketiga dari bawah diatas Zimbabwe dan Rusia dengan nilai dibawah 3,5 dan indeks kematian akibat kecelakaan sebesar 17-18 per 100.000 pekerja. Kondisi ini disebabkan karena masih kurangnya kesadaran dan pemahaman kalangan usaha di Indonesia akan pentingnya aspek K3 sebagai salah satu unsur untuk meningkatkan daya saing.

Keselamatan pada dasarnya adalah kebutuhan setiap manusia dan menjadi naluri dari setiap makhuk hidup. Sejak manusia bermukim di muka bumi, secara tidak sadar mereka telah mengenal aspek keselamatan untuk mengantisipasi berbagai bahaya disekitar lingkungan hidupnya. Pada masa itu, tantangan bahaya yang dihadapi lebih bersifat natural seperti kondisi alam, cuaca dan bahaya dari lingkungan hidup lainnya.

\section{MATERI DAN METODE}

\section{Manajemen Sumber Daya Manusia}

Menurut Handoko (2000) definisi Manajemen Sumber Daya Manusia sebagai berikut. Manajemen Sumber Daya Manusia adalah penarikan, seleksi, pengembangan, pemeliharaan, dan penggunaan sumber daya manusia untuk mencapai baik tujuan-tujuan individu maupun organisasi.

Dari definisi ini menekankan keberhasilan pengelola organisasi sangat ditentukan oleh kegiatan pendayagunaan sumber daya manusia. Oleh karena itu dalam membahas Keselamatan, Kesehatan dan Kerja (K3) sangatlah berkesinambungan mengingat K3 merupakan tujuan organisasi.

Menurut Abdurrahmat (2006) Manajemen sumber daya manusia yang mempunyai tinjauan wawasan masa depan harus mempunyai program memasukan sistem Keselamatan dan Kesehatan Kerja (K3) bagi karyawan dalam organisasi.

\section{Keselamatan dan Kesehatan Kerja (K3) Keselamatan Kerja}

Menurut Suma'mur (2001) mendefinisikan Keselamatan kerja merupakan rangkaian usaha untuk menciptakan suasana kerja yang aman dan tentram bagi para karyawan yang bekerja di perusahaan yang bersangkutan.

Menurut Mathis dan Jackson (2002), bahwa definisikan keselamatan adalah merujuk pada perlindungan terhadap kesejahteraan fisik seseorang terhadap cedera yang terkait dengan pekerjaan. Kesehatan adalah merujuk pada 
kondisi umum fisik, mental dan stabilitas emosi secara umum.

\section{Kesehatan Kerja}

Program kesehatan kerja merupakan suatu hal yang penting dan perlu diperhatikan oleh pihak perusahaan. Karena dengan adanya program kesehatan yang baik akan menguntungkan para karyawan secara material, karena karyawan akan lebih jarang absen, bekerja dengan lingkungan yang lebih menyenangkan, sehingga secara keseluruhan karyawan akan mampu bekerja lebih lama.

Menurut Mangkunegara (2011) Program kesehatan kerja menunjukkan pada kondisi yang bebas dari gangguan fisik, mental, emosi atau rasa sakit yang disebabkan oleh lingkungan kerja. Resiko kesehatan merupakan faktor-faktor dalam lingkungan kerja yang bekerja melebihi periode waktu yang ditentukan, Lingkungan yang dapat membuat stress emosi atau gangguan fisik.

Menurut Moenir (2006) yang dimaksud kesehatan kerja adalah suatu usaha dan keadaan yang memungkinkan seseorang mempertahankan kondisi kesehatannya dalam pekerjaan. Menurut Silalahi dan Rumondang (2000) menyatakan kesehatan kerja yaitu terhindarnya dari penyakit yang mungkin akan timbul setelah memulai pekerjaannya.

\section{Keselamatan dan Kesehatan Kerja (K3)}

Keselamatan dan Kesehatan Kerja sebagai suatu program didasari pendekatan ilmiah dalam upaya mencegah atau memperkecil terjadinya bahaya (hazard) dan risiko (risk) terjadinya penyakit dan kecelakaan, maupun kerugiankerugian lainya yang mungkin terjadi. Jadi dapat dikatakan bahwa Keselamatan dan Kesehatan Kerja adalah suatu pendekatan ilmiah dan praktis dalam mengatasi potensi bahaya dan risiko kesehatan dan keselamatan yang mungkin terjadi. (Rijanto, 2010) Menurut Abdurrahmat (2006) Manajemen sumber daya manusia yang mempunyai tinjauan wawasan masa depan harus mempunyai program memasukan sistem keselamatan dan kesehatan kerja (K3) bagi karyawan dalam organisasi. Pelaksanaan program keselamatan dan kesehatan kerja (K3) adalah salah satu bentuk upaya untuk menciptakan tempat kerja yang aman, sehat, bebas dari pencemaran lingkungan, sehingga dapat mengurangi dan atau bebas dari kecelakaan kerja dan penyakit akibat kerja yang pada akhirnya dapat meningkatkan efisiensi dan produktivitas kerja. Menurut (Suardi, 2007) bahwa dalam proses industrialisasi tidak lepas dari peranan tenaga kerja, oleh karena itu membangun tenaga kerja yang produktif, sehat dan berkualitas perlu memperhatikan faktor keselamatan dan kesehatan kerja (K3).

\section{Penyakit Kerja}

Penyakit kerja adalah kondisi abnormal atau penyakit yang disebabkan oleh kerentanan terhadap faktor lingkungan yang terkait dengan pekerjaan. Hal ini meliputi penyakit akut dan kronis yang disebabkan oleh pernafasan, penyerapan, pencernaan, atau kontak langsung dengan bahan kimia beracun atau pengantar yang berbahaya (Dessler, 2007).

\section{Kecelakaan Kerja}

Kecelakaan kerja adalah suatu kejadian yang tidak dikehendaki dan tidak diduga semula yang dapat menimbulkan korban jiwa dan harta benda (Peraturan Menteri Tenaga Kerja (Permenaker) Nomor: 03/Men/1998). Menurut (OHSAS 18001, 1999) dalam Shariff (2007).

Berdasarkan UU No. 1 Tahun 1970 tentang keselamatan kerja, kecelakaan kerja adalah suatu kejadian yang tidak diduga semula dan tidak dikehendaki, yang mengacaukan proses yang telah diatur dari suatu aktivitas dan dapat menimbulkan kerugian baik korban manusia maupun harta benda.

\section{Desain Penelitian}

Penelitian ini dilakukan untuk memperoleh gambaran bagaimana program keselamatan, kesehatan kerja (K3) pada PT. Hanei Indonesia terhadap tingkat penyakit kerja dan tingkat kecelakaan.

Metodologi Penelitian pada dasarnya merupakan cara ilmiah untuk mendapatkan data dengan tujuan dan kegunaan tertentu. Cara ilmiah berarti kegiatan penelitian didasarkan pada ciri-ciri keilmuan menurut Sugiyono (2011). Ciri-ciri keilmuan tersebut berarti dilakukan dengan cara-cara yang masuk akal, cara yang dilakukan dapat diamati dan 
dilakukan orang lain, proses yang digunakan menggunakan langkah yang bersifat logis.

Rumusan masalah dalam penelitian ini berbentuk deskriptif verifikatif. Menurut Sugiyono (2011) yang mendefinisikan deskriptif yaitu rumusan masalah yang berkenaan dengan pertanyaan terhadap keberadaan variabel mandiri, baik hanya satu variabel atau lebih. Sedangkan metode verifikatif merupakan penelitian yang bertujuan untuk mengetahui hubungan antara dua variabel atau lebih.

Berdasarkan sifatnya, jenis data yang dipergunakan dalam penelitian ini adalah data kuantitatif. Menurut Sugiyono (2011) Data kuantitatif merupakan suatu karakteristik dari suatu variabel yang nilai-nilainya dinyatakan dalam bentuk numerical. Dengan menggunakan teknik analisis regresi linear sederhana. Untuk menentukan erat atau tidaknya hubungan antara kedua variabel tersebut digunakan analisis korelasi.

\section{Analisis Regresi Sederhana}

Analisis regresi sederhana adalah suatu alat analisis peramalan nilai pengaruh variabel bebas terhadap variabel terikat untuk membuktikan ada atau tidaknya hubungan fungsi atau hubumgan kausal antara variabel bebas atau lebih dengan suatu variabel terikat. Riduan dan Akdon (2009). Dengan rumus sebagai berikut :

$$
\begin{gathered}
Y_{1}=a+b_{1} X \\
Y_{2}=a+b_{2} X \\
a_{i}=\frac{\sum Y_{i}-b\left(\sum X\right)}{n} \\
b_{i}=\frac{\sum\left(X Y_{i}\right)-\left(\sum X\right)\left(\sum Y_{i}\right)}{n\left(\sum X^{2}\right)-\left(\sum X\right)^{2}}
\end{gathered}
$$

Dimana :

$\mathrm{a}=$ Konstanta

$\mathrm{b}=$ Koefisien regresi

$\mathrm{X}$ = Biaya Keselamatan dan Kesehatan Kerja

$\mathrm{Y} 1=$ Penyakit Kerja

$\mathrm{Y} 2=$ Kecelakaan Kerja

\section{Analisis Koefisien Korelasi Sederhana}

Menurut Sarwono (2006) menjelaskan bahwa analisis koefisien korelasi pearson adalah sebagai berikut, analisis koefisien korelasi pearson digunakan untuk mengukur kuat lemahnya hubungan antara satu variabel bebas dan satu variabel tergantung. Dengan formulasi sebagai berikut:

$$
\begin{aligned}
& r_{1}=\frac{n \sum X Y_{1}-\left(\sum X\right)\left(\sum Y_{1}\right)}{\sqrt{\left.\left\{n\left(\sum X^{2}\right)-\left(\sum X\right)^{2}\right) n\left(\sum Y_{1}^{2}\right)-\left(\sum Y_{1}\right)^{2}\right\}}} \\
& r_{2}=\frac{n \sum X Y_{2}-\left(\sum X\right)\left(\sum Y_{2}\right)}{\sqrt{\left\{n\left(\sum X^{2}\right)-\left(\sum X\right)^{2}\right)\left(n\left(\sum Y_{2}^{2}\right)-\left(\sum Y_{2}\right)^{2}\right\}}}
\end{aligned}
$$

Dimana :

$\mathrm{r} \quad=$ Koefisien korelasi.

$\mathrm{r}^{1}=$ Koefisien korelasi antara biaya Keselamatan dan Kesehatan Kerja (K3) dengan penyakit kerja.

$\mathrm{r}^{2}=$ Koefisien korelasi antara biaya Keselamatan dan Kesehatan Kerja (K3) dengan tingkat kecelakaan kerja.

$\mathrm{n}=$ Periode waktu.

$\mathrm{X}=$ Variabel Independen Keselamtan, kesehatan kerja).

Y1 = Variabel dependen (Tingkat Penyakit kerja).

Y2 = Variabel dependen $\quad($ Kecelakaan kerja).

Untuk mengetahui hubungan variabelvariabel tersebut dapat dinyatakan dengan $r$ atau koefisien korelasi, dimana $\mathrm{r}$ terletak antara -1 hingga +1 .

a) Jika $\mathrm{r}=+1$ atau mendekati 1, maka hubungan variabel tersebut dikatan positif dan sangat kuat.

b) Jika $\mathrm{r}=-1$ atau mendekati -1, maka hubungan variabel tersebut dikatakan negative dan sangat kuat.

c) Jika $\mathrm{r}=0$ atau mendekati 0 , maka hubungan tersebut dikatakan sangat lemah atau tidak terdapat hubungan sama sekali.

\section{Koefisien Determinasi (KD)}

Koefisien ini disebut koefisien penentu, karena varian yang terjadi pada variabel dependen dapat dijelaskan melalui varian yang terjadi pada variabel independen. Koefisien determinasi dihitung dengan cara mengkuadratkan hasil korelasi kemudian dikalikan 100\% menurut Sugiyono (2011). Dengan rumus sebagai berikut :

$$
\begin{aligned}
& \mathrm{KD} 1=(\mathrm{r} 1)^{2} \times 100 \% \\
& \mathrm{KD} 2=(\mathrm{r} 2)^{2} \times 100 \%
\end{aligned}
$$


Dimana :

KD1 = Koefisien Determinasi K3 dan Jumlah Penyakit Kerja

KD2 = Koefisien Determinasi K3 dan Jumlah Kecelakaan Kerja

r1 = Koefisien korelasi K3 dengan Penyakit Kerja

r2 = Koefisien korelasi K3 dengan Kecelakaan Kerja

\section{Uji Hipotesis (Uji t)}

Pengujian ini dilakukan untuk mengetahui signifikasi pengaruh satu variabel independen secara parsial (individual) terhadap variabel dependen dengan hipotesis sebagai berikut :

1. Merumuskan Hipotesis

a. Ho : $\beta 1 \geq 0$, maka keselamatan dan kesehatan kerja tidak berpengaruh terhadap jumlah penyakit kerja.

b. Ha : $\beta 1<0$, maka keselamatan dan kesehatan kerja berpengaruh terhadap jumlah penyakit kerja.

c. Ho : $\beta 2 \geq 0$, maka keselamatan dan kesehatan kerja tidak berpengaruh terhadap jumlah kecelakaan kerja.

d. Ha : $\beta 2<0$, maka keselamatan dan kesehatan kerja berpengaruh terhadap jumlah kecelakaan kerja.

2. Menetukan tingkat signifikasi $(\alpha)$. Degree of freedom ( $d f$ ) dengan rumus : n-k-1

3. Menurut Sugiyono (2011) untuk menentukan nilai t hitung, dengan rumus sebagai berikut:

$\mathrm{t}=\frac{r \sqrt{n-2}}{\sqrt{1-r^{2}}}$

Dimana :

$$
\begin{aligned}
& \mathrm{R}=\text { Koefisien } \\
& \mathrm{t}=\mathrm{t} \text { hitung } \\
& \mathrm{n}=\text { Jumlah sampel }
\end{aligned}
$$

Dengan derajat kepercayaan 95\%, maka kriteria pengujian ditentukan sebagai berikut.

1. Jika $t_{\text {hitung }}<t_{\text {tabel }}$ dengan $\alpha=0,05$ maka Ho diterima $\mathrm{Ha}$ ditolak, berarti keselamatan dan kesehatan kerja tidak mempunyai pengaruh terhadap jumlah penyakit kerja.

2. Jika $t_{1 \text { hitung }} \geq t_{\text {tabel }}$ dengan $\alpha=0,05$ maka Ho ditolak dan $\mathrm{Ha}$ diterima, berarti keselamatan dan kesehatan kerja mempunyai pengaruh terhadap jumlah penyakit kerja.
3. Jika $t_{2 h i t u n g}<t_{\text {tabel }}$ dengan $\alpha=0,05$ maka Ho diterima Ha ditolak, berarti keselamatan dan kesehatan kerja tidak mempunyai pengaruh terhadap jumlah kecelakaan kerja.

4. Jika $t_{2 h i t u n g} \geq t_{\text {tabel }}$ dengan $\alpha=0,05$ maka Ho ditolak dan $\mathrm{Ha}$ diterima, keselamatan dan kesehatan kerja mempunyai pengaruh terhadap jumlah kecelakaan kerja.

Dari uji hipotesa diatas dilakukan uji satu pihak dengan tingkat signifikan $5 \%(0,05)$.

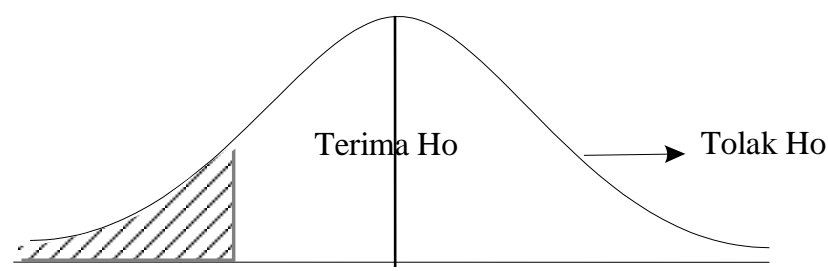

\section{HASIL DAN PEMBAHASAN}

Dari hasil analisis pada PT. Hanei Indonesia terdapat program Keselamatan Kerja, Kesehatan Kerja dan Bentuk unit kerja pada PT. Hanei Indonesia yaitu safety dan health department yang berada di bawah koordinasi human resource dan general affair division (HR\&GAD). human resource dan general affair division.

\section{Program Keselamatan dan Kesehatan Kerja (K3) pada PT. Hanei Indonesia}

Program Keselamatan dan Kesehatan Kerja (K3) merupakan upaya perusahaan dalam menciptakan kondisi kerja yang aman dan tenang sehingga dapat mencegah dan menanggulangi terjadinya kecelakaan kerja dan penyakit kerja oleh lingkungan dan kondisi kerja perusahaan yang kurang baik. Dengan adanya upaya untuk mengatasi masalah tersebut karyawan yang bekerja akan menjadi lebih nyaman. Program Keselamatan dan Kesehatan Kerja (K3) yang dilaksanakan oleh perusahaan adalah bagian dari program pemeliharaan karyawan untuk kesejahteraan karyawan. Pelaksanaan program Keselamatan dan Kesehatan Kerja (K3) yang dilakukan PT. Hanei Indonesia dalam rangka memenuhi kebutu han karyawan dan diharapkan dapat menjadi pendorong kinerja karyawan.

Program Keselamatan Kerja pada PT. Hanei Indonesia 
Keselamatan kerja merupakan hal yang penting untuk diperhatikan karena keselamatan kerja adalah keselamatan yang berhubungan dengan kegiatan perusahaan. Adapun tujuan dari keselamatan kerja adalah agar setiap tenaga kerja merasa terlindungi dalam melaksanakan pekerjaannya dan terhindar dari kecelakaan kerja yang mungkin timbul, program keselamatan kerja yang ada pada PT. Hanei Indonesia adalah sebagai berikut :

\section{a. Induksi K3}

Induksi K3 adalah pembekalan dan sosialisasi pemahaman $\mathrm{K} 3$ di area kerja sebelum kerja dimulai, kegiatan ini dilakukan oleh semua pekerja yang isinya berupa arahan-arahan kerja yang bertujuan agar prosedur kerja berjalan khususnya prosedur K3 yang di arahkan oleh kepala HSE atau ahli K3 yang dimiliki oleh PT. Hanei Indonesia.

\section{b. Formulir catatan dan surat ijin kerja (SIK)}

Formulir catatan adalah surat yang dikeluarkan oleh departement EHS kepada para pelaku safety yang akan bekerja agar mematuhi kebijakan K3 yang telah ditetapkan.

\section{c.Inpeksi K3}

Inspeksi merupakan salah satu cara untuk menemukan potensi sumber bahaya yang ada ditempat kerja agar dapat segera diperbaiki sebelum potensi bahaya tersebut menimbulkan kecelakaan. Sesuai dengan Permenaker 05/MEN/96. kegiatan ini dilakukan oleh ahli K3 yang memeriksa semua keadaan area kerja saat proses kerja dilaksanakan agar hal-hal yang tidak diinginkan tidak terjadi.

\section{d. Emergency Planning}

Emergency Planning pada hakekatnya dilakukan untuk menghadapi keadaan darurat yang terjadi yaitu meliputi kejadian kebakaran, sabotase, peledakan, tumpahan bahan kimia dan kejadian lain yang menghambat proses kerja.

e. Investigation

Setiap kecelakaan kerja yang terjadi harus dilaporkan pada pihak yang bertanggung jawab dan harus dibuat berita acara kejadiannya yang meliputi tempat kejadian, tindakan pertolongan dan saksi. Investigasi merupakan upaya mencari penyebab yang menyertai suatu kecelakaan berupa pendataan terhadap kejadian kecelakaan. f. Penyediaan Alat Pelindung Diri (APD)

Berdasarkan Undang- undang No.1 Tahun 1970 tentang Keselamatan dan Kesehatan Kerja, yaitu pasal 14 (c), perusahaan menyediakan alat pelindung diri berupa APD (Alat Pelindung Diri) bagi Karyawan maupun tamu yang berkunjung ke perusahaan. Berikut adalah APD yang disediakan perusahaan :

1. Safety Helmet, berfungsi sebagai pelindung kepala dari benda yang bisa mengenai kepala secara langsung.

2. Tali Keselamatan (Safety Belt), berfungsi sebagai alat pengaman ketika menggunakan alat transportasi ataupun peralatan lain yang serupa (mobil, pesawat, alat berat, dan lain-lain)

3. Sepatu Karet (Sepatu Boot), berfungsi sebagai alat pengaman saatbekerja di tempat yang becek ataupun berlumpur.

4. Sepatu Pelindung (Safety Shoes), berfungsi untuk mencegah kecelakaan fatal yang menimpa kaki karena tertimpa benda tajam atau berat, benda panas, cairan kimia, dan sebagainya.

5. Sarung Tangan, berfungsi sebagai alat pelindung tangan pada saat bekerja di tempat atau situasi yang dapat mengakibatkan cedera tangan.

6. Tali Pengaman (Safety Harness), berfungsi sebagai pengaman saat bekerja di ketinggian.

7. Penutup Telinga (Ear Plug/ Ear Muff), berfungsi sebagai pelindung telinga pada saat bekerja di tempat yang bising.

8. Kacamata Pengaman (Safety Glasses), berfungsi sebagai pelindung mata ketika bekerja (misal mengelas).

9. Masker (Respirator), berfungsi sebagai penyaring udara yang dihirup saat bekerja di tempat dengan kualitas udara yang buruk (misal berdebu, beracun, berasap, dan sebagainya).

10. Pelindung Wajah (Face Shield), berfungsi sebagai pelindung wajah dari percikan benda asing saat bekerja (misal pekerjaan menggerinda).

11. Jas Hujan (Rain Coat), berfungsi melindungi diri dari percikan air saat bekerja (misal bekerja pada saat hujan atau sedang mencuci alat).

g. Rambu-rambu Keselamatan 
Pemberian rambu-rambu keselamatan adalah dalam rangka memberikan peringatan dan perintah kepada karyawan atau siapa saja yang akan memasuki area kerja di perusahaan agar mematuhi dan mengikuti aturan dan kebijakan $\mathrm{K} 3$ yang ada di perusahaan.

\section{h.Training K3}

Training K3 merupakan suatu upaya dalam memberikan pengetahuan dan hal-hal mengenai kebijakan dan prosedur K3 kepada karyawan. Dilakukan sekurang-kurangnya selama 120 jam pelajaran atau 12 hari jam efektif guna menjadi ahli K3 umum, kegiatan training dilakukan setiap adanya jadwal training oleh pihak pemerintah ataupun swasta.

\section{Program Kesehatan Kerja pada PT. Hanei Indonesia}

Kesehatan kerja merupakan faktor yang sangat penting dalam menunjang kinerja dan produktivitas karyawan. Oleh karena itu perusahaan memberikan perhatian yang besar terhadap pelayanan kesehatan kepada karyawan dan keluarganya, perusahaan memberikan pelayanan kesehatan ini dengan baik dan lengkap.

Tujuan dari pemberian pelayanan kesehatan ini adalah untuk mewujudkan derajat kesehatan yang optimal. Adapun bentuk pelayanan kesehatan yang diberikan adalah :

a. Penyediaan Poliklinik

Perusahaan menyediakan fasilitas pengobatan didalam perusahaan yaitu poliklinik yang buka setiap hari kerja.

b. Program Asuransi

Sesuai dengan Undang-Undang No.3 Tahun 1992 dan Perpres No. 12 Tahun 2013, PT.

Hanei Indonesia memberikan asuransi jaminan sosial kesehatan Jamsostek dan BPJS

c. Pemeriksaan Kesehatan

Pemeriksaan kesehatan yang dilakukan PT. Hanei Indonesia terhadap karyawannya meliputi :

1) Pemeriksaan awal

Pemeriksaan awal dilakukan karyawan yang akan direkrut, pemeriksaan dilakukan dengan medical check up. Semua biaya pemeriksaan kesehatan awal ini di biayai oleh pihak peusahaan pemeriksaan awal ini dilakukan agar setiap calon karyawan yang akan direkrut memiliki kesehatan yang baik.

2) Pemeriksaan berkala

Pemeriksaan berkala ini dilakukan untuk memelihara karyawan agar terjaga dalam keadaan sehat, ini dilakukan setiap satu minggu sekali yang dilakukan di poliklinik yang tersedia.

3) Pemeriksaan khusus

Pemeriksaan ini dilakukan kepada karyawan yang mengalami penyakit akibat kerja.

d. Sistem rujukan

Sistem rujukan ini adalah untuk tindak lanjut pengobatan yang memerlukan perawatan lebih intensif, RS. Amanda adalah rumah sakit yang menjadi rujukan yang beralamat jalan Serang no.13 Cikarang Selatan Bekasi

e. Pengolahan Limbah

Limbah yang terdapat pada perusahaan ini berbagai macam jenisnya seperti : plastik, kardus, sisa pekerjaan yang tidak terpakai lainnya yang dikelola secara baik.

f. Penyediaan obat-obatan dalam kotak P3K Penyediaan obat-obatan dalam kotak P3k pada setiap departement dalam upaya mencegah dan mengurangi dampak buruk akibat kecelakaan kerja dan penyakit kerja.

g. Penyediaan toilet dan kamar mandi Perusahaan menyediakan kamar mandi dan toilet untuk untuk laki-laki dan perempuan.

\section{Bentuk Unit K3 pada PT. Hanei Indonesia}

Bentuk unit kerja pada PT.Hanei Indonesia yaitu safety dan health department yang berada di bawah koordinasi human resource dan general affair division (HR\&GAD). human resource dan general affair division memiliki tugas diantaranya :

a. Mengikuti perkembangan teknologi dan informasi yang berkaitan dengan Keselamatan dan Kesehatan Kerja (K3) serta menyusun, mengkoordinasi dan mengembangkan program Keselamatan dan Kesehatan Kerja (K3) yang sesuai dengan peraturan perundangan yang berlaku.

b. Membuat sistem pencatatan dan pelaporan kinerja Keselamatan dan Kesehatan Kerja (K3) disetiap Plant dan divisi serta melakukan pengawasan keselamatan dan kesehatan kerja. 
Safety department merupakan suatu unit kerja yang mengurusi semua hal yang berkaitan dengan keselamatan kerja dan dalam melaksanakan programnya. Safety department dibantu oleh safety section, safety engineering group dan fire brigadesection.

Health department merupakan suatu unit kerja yang mengurusi semua hal yang berkaitan dengan kesehatan kerja dalam melaksanakan programnya. Health department dibantu oleh hazard monitoring section, health care section dan health service section.

\section{Biaya K3, Jumlah Penyakit Kerja dan Jumlah Kecelakaan Kerja pada PT. Hanei Indonesia}

Penyakit kerja adalah kondisi abnormal atau penyakit yang disebabkan oleh kerentanan terhadap faktor lingkungan yang terkait dengan pekerjaan. Hal ini meliputi penyakit akut dan kronis yang disebabkan oleh pernafasan, penyerapan, pencernaan, atau kontak langsung dengan bahan kimia beracun atau pengantar yang berbahaya (Dessler, 2007). Sedangkan

Kecelakaan kerja adalah suatu kejadian yang tidak dikehendaki dan tidak diduga semula yang dapat menimbulkan korban jiwa dan harta benda (Peraturan Menteri Tenaga Kerja (Permenaker) Nomor: 03/Men/1998).

Berikut merupakan data biaya $\mathrm{K} 3$, penyakit kerja dan tingkat kecelakaan pada PT. Hanei Indonesia, selama tahun 2008 sampai 2013

Tabel 1. Informasi Deskriptif

\begin{tabular}{|c|c|c|c|c|c|c|}
\hline Tahun & Biaya K3 & $\begin{array}{c}\text { \%o } \\
\text { Perubahan } \\
\text { Biaya K3 }\end{array}$ & $\begin{array}{c}\text { Jumlah } \\
\text { PK }\end{array}$ & \% PK & $\begin{array}{c}\text { Jumlah } \\
\text { KK }\end{array}$ & \% KK \\
\hline 2008 & Rp. 300.5000 .000 & & 30 & & 6 & \\
\hline 2009 & Rp. 350.000 .000 & $16,47 \%$ & 25 & $(16,66 \%$ & 5 & $(18 \%)$ \\
\hline 2010 & Rp. 4000000.000 & $14,28 \%$ & 20 & $(20 \%)$ & 5 & - \\
\hline 2011 & Rp. 410.512 .000 & $2,62 \%$ & 21 & $5 \%$ & 2 & $(40 \%)$ \\
2012 & Rp. 405.416 .000 & $(1,24 \%)$ & 14 & $(33 \%)$ & 3 & $18 \%$ \\
\hline 2013 & Rp. 425.876 .000 & $5,04 \%$ & 7 & $(50 \%)$ & 1 & $(40 \%)$ \\
\hline
\end{tabular}

Berdasarkan Tabel 1 masih terdapat penyakit kerja dan kecelakaan kerja pada PT. Hanei Indonesia. Terjadi peningkatan biaya K3 dari tahun 2008-2011 karena pada tahun itu terdapat penambahan pekerja, tetapi mengalami penurunan di tahun 2012 sebesar 1,24\% dan meningkat di tahun 2013, peningkatan itu terjadi karena adanya penambahan pekerja yang disebabkan adanya proyek tambahan ataupun target penyelesaian sehingga perusahaan berkewajiban mengedepankan keselamatan pekerja, pergantian alat-alat baru yang rusak.

Jumlah penyakit kerja yang di lihat dengan jumlah (orang) mengalami penurunan tahun 2008-2010 dan pada tahun 2011 meningkat sebesar 5\% ini terjadi karena proses kerja dari induksi, Standar Oprasional Prosedur (SOP) dan inpeksi kurang berjalan dengan baik. Pada tahun 2012-2013 jumlah penyakit kerja mengalami penurunan masing-masing sebesar $33 \%$ dan $50 \%$. Hal ini berkaitan dengan upaya dari perusahaan meminimalisasi faktor-faktor yang menyebabkan penyakit kerja.

Kecelakaan kerja mengalami punurunan pada tahun 2008-2011 dan pada tahun 2012 meningkat sebesar $18 \%$. Kenaikan kecelakaan kerja sebesar $18 \%$ juga disebabkan karena proses kerja dari induksi, Standar Oprasional Prosedur (SOP) dan inpeksi kurang berjalan dengan baik, sehingga menimbulkan kecelakaan kerja. Pada tahun 2013 jumlah kecelakaan kerja kembali turun sebesar $40 \%$, hal ini menunjukan bahwa perusahaan terus berupaya meminimalisasi kecelakaan kerja dan karyawan sudah mulai memiliki kesadaran pentingnya keselamatan kerja.

\section{Pengaruh Keselamatan dan Kesehatan Kerja (K3) terhadap Jumlah Penyakit Kerja}

a. Analisis Regresi

Untuk mengetahui pengaruh Keselamatan dan Kesehatan Kerja terhadap Jumlah Penyakit Kerja menggunakan analisis sebagai berikut :

\section{Tabel 2. Hasil Uji t}

Coefficients's

\begin{tabular}{|c|c|c|c|c|c|c|}
\hline \multirow{2}{*}{\multicolumn{2}{|c|}{ Model }} & \multicolumn{2}{|c|}{ Unstandardizad Coefiticients } & \multirow{2}{*}{$\frac{\text { Standasdized Coefficients }}{\text { Bata }}$} & \multirow[t]{2}{*}{$\bar{T}$} & \multirow[t]{2}{*}{$\mathrm{Sig}$} \\
\hline & & $B$ & Std Error & & & \\
\hline \multirow{2}{*}{1} & (Contant) & 75647 & 16.785 & & 4.507 & .011 \\
\hline & $\mathrm{X}$ & $-1470 \mathrm{E}-007$ & .000 & .860 & -3367 & .028 \\
\hline
\end{tabular}

Berdasarkan tabel tersebut, diperoleh persamaan regresi sederhana sebagai berikut:

$\mathrm{Y}=75,647-0,0000001470 \mathrm{X}_{1}+\mathrm{e}$

Jika biaya $\mathrm{K} 3$ sebesar $(\mathrm{X}=0)$ atau tidak ada, maka Jumlah penyakit kerja sebesar 75,647. Dengan asumsi jika biaya K3 meningkat sebesar 
Rp. 100.000.000 diduga akan menurunkan jumlah penyakit kerja sebesar 14,7 atau 14 orang. Persamaan regresi memiliki pengaruh negatif karena jika perusahaan mendukung program K3 yang bersifat pencegahan seperti APD (Alat Pelindung Diri), Rambu-rambu keselamatan, maka diduga akan meurunkan tingkat penyakit kerja.

\section{b.Analisis Korelasi Sederhana}

Analisis korelasi sederhana digunakan untuk mengetahui adanya hubungan antara Keselamatan dan Kesehatan Kerja (K3) terhadap Jumlah Penyakit Kerja dan Jumlah Kecelakaan Kerja. Berdasarkan pengolahan data menggunakan SPSS 20 For Windows diperoleh hasil sebagai berikut :

Tabel 3. Koefesien Korelasi

\begin{tabular}{|c|c|c|c|c|}
\hline \multicolumn{5}{|c|}{ Model Summary } \\
\hline Model & $R$ & R Square & $\begin{array}{l}\text { Adjusted R } \\
\text { Square }\end{array}$ & $\begin{array}{c}\text { Std. Error of the } \\
\text { Estmate }\end{array}$ \\
\hline 1 & 860 & .739 & .874 & 4.63554 \\
\hline
\end{tabular}

Korelasi sederhana (r) pada $\mathrm{T}$ abel 4.3 sebesar 0,860 yang berarti memiliki hubungan yang sangat kuat. Hal ini menunjukkan Biaya Keselamatan dan Kesehatan Kerja (K3) pada PT. Hanei memiliki hubungan yang sangat kuat dengan terhadap jumlah penyakit kerja. Jika biaya K3 meningkat maka jumlah penyakit kerja akan berkurang.

\section{c.Analisis Koefisien Determinasi}

Koefisien determinasi menunjukkan seberapa besar persentase sumbangan pengaruh variabel Keselamatan dan Kesehatan Kerja (K3) terhadap Jumlah Penyakit Kerja.

Berdasarkan Tabel diperoleh nilai $\mathrm{R}^{2}$ sebesar $0,739(73,9 \%)$. Hal ini menunjukkan bahwa persentase sumbangan pengaruh Biaya Keselamatan dan Kesehatan Kerja (K3) terhadap Jumlah Penyakit Kerja sebesar 73,9\%. Sedangkan 26,1\% lainnya dipengaruhi faktor lainnya seperti faktor fisik, faktor kimia, faktor infeksi, faktor fisiologis, faktor mental dan faktor psikologis (Notoatmodjo, 2007)

\section{Pengujian Hipotesis (Uji t)}

Uji t bertujuan untuk mengetahui signifikasi, apakah variabel Biaya Keselamatan dan
Kesehatan Kerja (K3) berpengaruh secara nyata terhadap variabel Jumlah Penyakit Kerja. Pengujian hipotesis dilakukan menggunakan uji $\mathrm{t}$ dengan tingkat signifikasi sebesar $\alpha=5 \%$. Adapun rumusan hipotesisnya sebagai berikut : Variabel Jumlah Penyakit Kerja

a. Ho : $\beta 1 \geq 0$, maka biaya keselamatan dan kesehatan kerja tidak berpengaruh terhadap jumlah penyakit kerja.

b. Ha : $\beta_{1}<0$, maka biaya keselamatan dan kesehatan kerja berpengaruh terhadap jumlah penyakit kerja.

Berdasarkan Tabel 2 diperoleh nilai $t_{\text {tab }}$ sebesar -3,367 ditentukan dengan menggunakan uji 1 pihak dengan tingkat signifikasi sebesar $0,05(\alpha=5 \%)$ dan derajat kebebasan (dk) n-k-1 atau $6-1-1=4$. Oleh karena $t_{\text {hit }}(-3,367)>t_{\text {tab }}(-$ 2,131) maka Ho diterima dapat disimpulkan bahwa biaya keselamatan dan kesehatan kerja berpengaruh terhadap jumlah penyakit kerja.

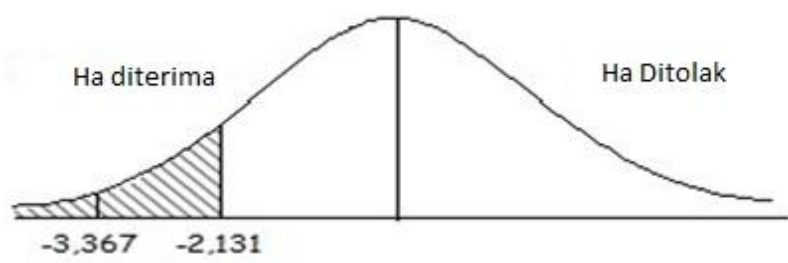

\section{Pengaruh Keselamatan dan Kesehatan Kerja (K3) terhadap Kecelakaan Kerja}

a. Analisis Regresi

Untuk mengetahui pengaruh Keselamatan dan Kesehatan Kerja terhadap jumlah kecelakaan kerja menggunakan analisis sebagai berikut

\section{Tabel 4. Hasil Uji t}

Coefficients $^{2}$

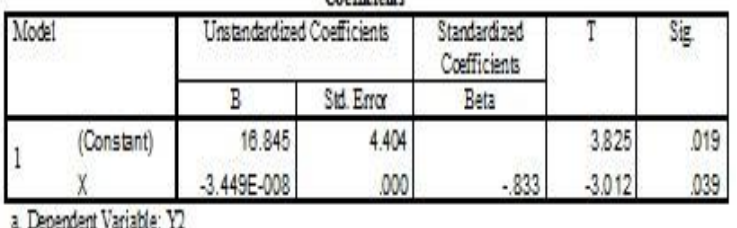

Berdasarkan tabel tersebut, diperoleh persamaan regresi sederhana sebagai berikut :

$\mathrm{Y}=16,845-0,00000003449 \mathrm{X}+\mathrm{e}$

Jika biaya $\mathrm{K} 3$ sebesar $(\mathrm{X}=0)$ atau tidak ada, maka jumlah kecelakaan kerja sebesar 16,845. Dengan asumsi jika biaya K3 meningkat sebesar Rp. 100.000.000 diduga akan menurunkan jumlah kecelakaan kerja sebesar 3,449 atau (3 
orang). Persamaan regresi memiliki pengaruh negatif karena jika perusahaan mendukung program K3 yang bersifat preventif (pencegahan) seperti APD (Alat Pelindung Diri), Rambu-rambu keselamatan, maka diduga akan menurunkan jumlah kecelakaan kerja dan sebaliknya.

\section{b. Analisis Korelasi Sederhana}

Analisis korelasi sederhana digunakan untuk mengetahui adanya hubungan antara Keselamatan dan Kesehatan Kerja (K3) terhadap Jumlah Kecelakaan Kerja. Berdasarkan pengolahan data menggunakan SPSS 20 For Windows diperoleh hasil sebagai berikut :

Tabel 5. Koefesien Korelasi

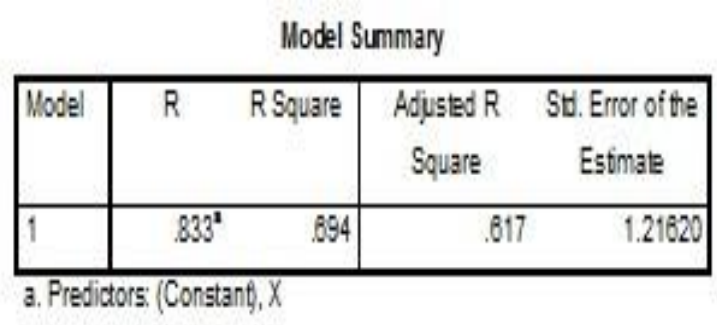

Korelasi sederhana (r) pada tabel 5 sebesar 0,833 yang berarti memiliki hubungan yang sangat kuat. Hal ini menunjukkan Biaya Keselamatan dan Kesehatan Kerja (K3) pada PT. Hanei memiliki hubungan yang sangat kuat terhadap Jumlah Kecelakaan Kerja.

\section{c. Koefisien Determinasi}

Koefisien determinasi menunjukkan seberapa besar persentase sumbangan pengaruh variabel Keselamatan dan Kesehatan Kerja (K3) terhadap Kecelakaan Kerja. Berdasarkan Tabel diperoleh nilai $\mathrm{R}^{2}$ sebesar $0,694 \quad(69,4 \%)$. Hal ini menunjukkan bahwa persentase sumbangan pengaruh Biaya Keselamatan dan Kesehatan Kerja (K3) terhadap Jumlah Kecelakaan Kerja sebesar 69,4\%. Sedangkan 20,6\% lainnya dipengaruhi faktor lainnya yang tidak dimasukkan dalam model penelitian seperti faktor human eror, faktor lingkungan kerja, kondisi fisik, pengaturan udara, pengaturan penerangan, pemakaian APD, mental pegawai (Mangkunegara 2011).

\section{d. Pengujian Hipotesis (Uji t)}

Uji t bertujuan untuk mengetahui signifikasi, apakah variabel Biaya Keselamatan dan Kesehatan Kerja (K3) berpengaruh secara nyata terhadap variabel Kecelakaan Kerja. Pengujian hipotesis dilakukan menggunakan uji t dengan tingkat signifikasi sebesar $\alpha=5 \%$. Adapun rumusan hipotesisnya sebagai berikut :

a. Ho : $\beta 2 \geq 0$, maka keselamatan dan kesehatan kerja tidak berpengaruh terhadap jumlah kecelakaan kerja.

b. Ha : $\beta 2<0$, maka keselamatan dan kesehatan kerja berpengaruh terhadap jumlah kecelakaan kerja.

Berdasarkan Tabel diperoleh nilai tab sebesar 2,131 ditentukan dengan menggunakan uji 1 pihak dengan tingkat signifikasi sebesar 0,05 ( $\alpha$ $=5 \%)$, dan derajat kebebasan (dk) n-k-1 atau 6$1-1=4$. Oleh karena $t_{\text {hit }}(-3,012)>t_{\text {tab }}(-2,131)$, maka Ho diterima. Dapat disimpulkan bahwa biaya $\mathrm{K} 3$ berpengaruh nyata terhadap terhadap jumlah kecelakaan kerja

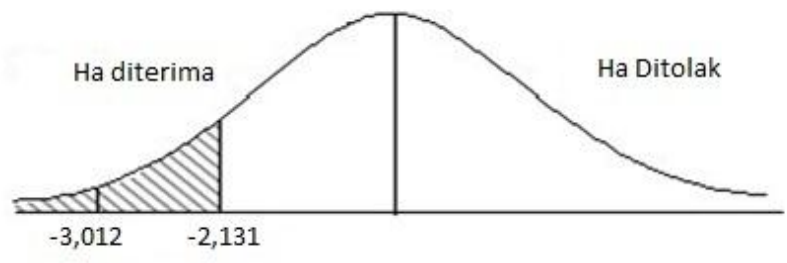

\section{KESIMPULAN DAN IMPLIKASI}

Berdasarkan hasil penelitian pada PT. Hanei Indonesia bahwa :

1. Program Keselamatan dan Kesehatan Kerja (K3) pada PT. Hanei Indonesia merupakan bagian dari program pemeliharaan karyawan agar setiap karyawan merasa terlindungi dalam melaksanakan pekerjaan dan terhindar dari penyakit kerja dan kecelakaan kerja. Dukungan perusahaan terhadap program K3 yang berhubungan dengan keselamatan kerja meliputi penyediaan Alat Pelindung Diri (APD), ramburambu keselamatan. Dukungan perusahaan yang berkaitan dengan kesehatan kerja meliputi penyediaan poliklinik, asuransi, pemeriksaan kesehatan, sistem rujukan, pengolahan limbah, penyediaan obat-obatan dan penyediaan sarana toilet. PT. Hanei Indonesia membentuk unit kerja K3 yaitu safety dan health department yang berada dibawah koordinasi human 
resource dan general affair division guna mengembangkan program $\mathrm{K} 3$ ke arah yang lebih baik.

2. Jumlah penyakit kerja pada PT. Hanei Indonesia mengalami fluktuasi dari tahun 2008 sampai 2013 ini terjadi karena faktor-faktor yang menjadi sebab penyakit kerja di area kerja masih ditemukan seperti suara bising, debu, cairan kimia dan lainnya yang kurang penanganannya. Pengaruh biaya Keselamatan dan Kesehatan Kerja (K3) terhadap jumlah penyakit kerja pada PT. Hanei Indonesia :

a. Berdasarkan hasil regresi pengaruh biaya K3 terhadap jumlah penyakit kerja memiliki pengaruh yang negatif artinya jika biaya K3 meningkat diduga akan menurunkan jumlah penyakit kerja. Hubungan antara biaya K3 terhadap jumlah penyakit kerja memiliki hubungan yang sangat kuat.

b. Berdasarkan hasil uji t Biaya Keselamatan dan Kesehatan Kerja (K3) berpengaruh nyata terhadap jumlah penyakit kerja.

3. kecelakaan kerja pada PT. Hanei Indonesia mengalami fluktuasi dari tahun 2008 sampai 2013 ini terjadi karena proses kerja dari induksi, investigasi, prosedur kerja, emergency plan, penyediaan APD dan ramburambu keselamatan tidak berjalan optimal oleh seluruh pelaku safety karena masih adanya kecelakaan kerja yang masih terjadi. Hal tersebut perlu di evaluasi mengingat kecelakaan kerja adalah hal yang harus di minimalisir setiap tahunnya sampai tidak terdapat kecelakaan kerja (zero accident). Pengaruh Biaya Keselamatan dan Kesehatan Kerja (K3) terhadap kecelekaan Kerja pada PT. Hanei Indonesia :

a. Berdasarkan hasil regresi pengaruh biaya K3 terhadap jumlah kecelakaan kerja memiliki pengaruh yang negatif artinya jika biaya K3 meningkat di uga akan menurunkan jumlah kecelakaan kerja.
Hubungan antara biaya K3 terhadap jumlah kecelakaan kerja memiliki hubungan yang sangat kuat.

b. Berdasarkan hasil uji t Biaya Keselamatan dan Kesehatan Kerja (K3) berpengaruh nyata terhadap jumlah kecelakaan kerja.

Berdasarkan hasil penelitian yang telah dilakukan, penulis mencoba memberikan saran sebagai berikut:

1. Sebaiknya pihak perusahaan PT. Hanei Indonesia, meningkatkan pengawasan yang lebih intensif terhadap karyawan agar jumlah penyakit kerja dan jumlah kecelakaan kerja sesuai dengan target yang telah ditetapkan yaitu zero accident.

2. Pegawai sebaiknya meningkatkan kesadaran akan pentingnya faktor keselamatan dan kesehatan kerja, untuk mencapai hasil kerja yang maksimal.

3. Saran untuk penelitian lanjutan

a. Masukan variabel lain yang tidak diteliti dalam penelitian ini yang berhubungan dengan penyakit kerja seperti faktor manusia, faktor fisik, faktor kimia, faktor infeksi, faktor fisiologis, faktor mental psikologis dan faktor lingkungan.

b. Masukan variabel lain yang tidak diteliti dalam penelitian ini yang berhubungan dengan kecelakaan kerja seperti pemakaian alat pelindung diri, mental pegawai, faktor penerangan, kondisi fisik.

\section{DAFTAR PUSTAKA}

Dessler, Gary. 2003. Manajemen Sumber Daya Manusia. Alih Bahasa Paramita Rahayu. Edisi Kesepuluh. Prehalindo : Jakarta

Fathoni, Abdurrahmat. 2006. Organisasi dan Manajemen Sumber Daya Manusia. Rineka Cipta : Jakarta

Hariandja, Marihot. 2002. Manajemen Sumber Daya Manusia. PT Grasindo. Jakarta

2005. Manajemen Sumber Daya Manusia. Grasindo : Jakarta

Malthis, Robert L. dan John H. Jackson. 2002. Manajemen Sumber Daya 
Jakarta

Manusia. Salemba Empat :

Mangkunegara, A.A. Anwar Prabu. 2011. Manajemen Sumber Daya Manusia Perusahaan. Penerbit PT Remaja Rosdakarya : Bandung

Manullang, Sendjun H. 2000. Pokok-pokok Hukum Keternagakerjaan Indonesia. Rineka Cipta : Jakarta

Moenir, H.A.S. 2006. Pendekatan Manusia dan Organisasi Terhadap Pembinaan Kepegawaian. Bumi Aksara : Jakarta

Mondy, R. Wayne. 2008. Manajemen Sumber Daya Manusia, Edisi 10 jilid 2. Erlangga : Jakarta

Rijanto, Budi.,2010. Pedoman praktis keselamatan, kesehatan kerja dan lingkungan, Mitra Wacana Media : Indonesia.
Schuler, Randall S. dan Susan E. Jackson. 1999. Manajemen Sumber Daya Manusia Menghadapi Abad Ke-21. Erlangga : Jakarta

Sugiyono. 2011. Metode Penelitian Kuantitatif, kualitatif dan R \& D. Alfabeta : Bandung

Suma'mur. 2001. Keselamatan Kerja dan Pencegahan Kecelakaan. Gunung Agung : Jakarta

Syukri Sahab, 1997. Teknik Manajemen Keselamatan dan Kesehatan Kerja. Bina Sumber Daya Manusia : Jakarta

Wibowo. 2007. Manajemen Kinerja, edisi ketiga. PT Raja Grafindo Persada : Jakarta

Winardi, J. 2004. Manajemen Perilaku Organisasi, Edisi Revisi. Prenada Media : Jakarta 